\title{
Municipal Councils in Saudi Arabia: Context and Organization
}

\author{
Waleed Abdullah Abdulaal \\ Department of Urban and Regional Planning, Faculty of Environmental \\ Design, King Abdulaziz University, Jeddah - Saudi Arabia
}

(Received: 13/05/2006, Accepted: 1/1/2008)

\begin{abstract}
In 2004 the Saudi Council of Ministers called for the formation of semi-elected municipal councils in 178 cities and towns of Saudi Arabia. This command instigated public participation in local decision making. The election process finished in early 2005 and councils' formation is completed by the end of 2005 to augment their start. Given the relatively fresh beginning of citizen engagement in local decisions in Saudi Arabia, this paper aims at analyzing the context and organization of municipal councils in Saudi Arabia. The paper starts by reviewing theoretical background on public participation, highlighting its importance, methods and factors affecting it. The purpose is to establish an analytical framework to examine the work in Saudi. Two sets of interrelated factors are defined including contextual and local factors, which are then discussed in relation to municipal councils in Saudi Arabia. The discussion outlines existing shortcomings with the contextual and local factors and proposes necessary improvements based on the understanding that public participation is a learning process that will demand continuous improvement and enhancement.
\end{abstract}

Keywords: Municipal Councils, Public Participation, Urban Management.

\section{Introduction}

Municipalities in Saudi Arabia form one part of the local administration which includes; the Amara "Governate" and the local units controlled by their respective central ministries. Therefore, management of urban development, to a large extent, is not exercised by municipalities alone, reflecting some form of fragmentation of responsibilities. Public 
participation in the decision making process of shattered local administrative structure had been so minimal and incapacitated. The law of Municipality of Makkah and other Municipalities (1954) called for the establishment of municipal councils with elected members from the general public which was also reiterated by the Law of Municipalities and Villages (1977). The formation process of municipal councils was crumbled and faced with insufficient attention. Municipal councils were limited to a few municipalities with inadequate participation in municipal administration. A serious request for public involvement in municipal administration came from the Council of Ministers in 2004 $4^{[1]}$. Accordingly, the constitution method of municipal councils started from that time and councils are finally formed and began their functions in late 2005. Apparently, it is premature to assess the performance of municipal councils for the time being, but it worth shedding some light on their role and examine the context within which they function and their potential effect on municipal decisions and urban management, which becomes the focus of this paper. The paper starts by reviewing theoretical background on public participation at the local level focusing on its importance, methods, roles, and factors affecting participation as covered in Section 2. The purpose is to explore abstract reference for Municipal Councils (also called local councils) to establish a framework for studying the Saudi case. Focus here is given to United Kingdom's experience and few Western countries like Canada and France. The aim here is not to look at parallel examples due to limited references in Islamic and Arab countries, but the review is conducted as a learning tool to define important elements related to public participation including their importance, challenges, methods and factors effecting their performance. The framework highlights two inter-related set of factors that affect public participation, namely; contextual factors, and local factors, this framework paves the way on studying municipal councils in Saudi Arabia which begins at section 4 by reviewing development of municipal councils, then applying the analytical framework as covered in sections 5,6 and 7 .

\section{Public Participation}

\subsection{Importance}

Community engagement is a major constituent of the governance of urban areas by local authorities in countries that apply public 
participation. Community participation is usually prescribed within the legislation that specifies the degree and depth of participation. The legislative framework governing community engagement varies between countries but usually institutes duties on public participation and accountability to decision making at the local level. In fact, regulations in democratic governments call upon local authorities to incorporate the community in the decision making process, which may also be regarded as consultation. For Islamic countries the Holy Quran established the principle of consultation 14 centuries ago by requesting Prophet Mohammad (PBUH) to consult his companions. Literature on local governance and participation is extensive and tends to focus on two broad themes - debate on what is regarded as consultation and assertions about the benefits of consultation to the quality of decision making or to governance in general. Definition of participation focus on the involvement of citizens in decision making ${ }^{[2]}$ by methods which vary among countries. Participation in local democracies is based on four concepts; ${ }^{[3]}$ (a) Popular authorization of decision making, where elected local leaders take decisions on behalf of the community. (b) Accountability, the government is answerable to the public through a transparent system that ensures the availability of information on government work and achievements. (c) Responsiveness, local authority should take account of the full range of public opinion, react to demands and set priorities. (d) Representativeness, to ensure equality of citizenship in the election process.

Others propose a similar view with little variation, for example Walsh and Sarkissian $(2001)^{[4]}$ uses the expression the "wheel of participation" compounding four elements; information, consultation, participation and empowerment. Further contribution came from Chanan $(1997)^{[5]}$ proposing the pyramid of participation with both vertical and horizontal forms of public engagement. He calls for expediting participation at both lower and higher levels. The lower levels engage large number of citizens while the higher levels of participation develop people's capacities for their own benefits. Further understating to the concept of participation may be stemmed from the aims of consultation over political management arrangement ${ }^{[6]}$, as follows:

- Information - to provide information and opportunities for the public to be better informed 
- Learning - to listen and learn from the public; and

- Exchange - to define issues and discuss problems and solutions with the public.

These complementing views on consultation pave the way to understand its benefits that include (i) the creation of a more transparent and accountable government, (ii) improves the quality of services as they consider public needs, and (iii) encourages good management aiming to achieve better results ${ }^{[7]}$. Effective public participation in the decision making process enables the public to voice their demands and opinions, and the decision maker to take account of suggestions and concerns that may be relevant to decisions ${ }^{[8]}$. Participation can improve the availability of decisions, resolve conflicts among competing interests, building trust on institutions and educating and informing the public ${ }^{[9]}$. Infact participation in local policy making may be notably beneficial because communities are usually important elements in the solutions to local problems. Further, public engagement in decision making can have a real impact on resources, expectations and internal processes ${ }^{[10]}$. Usually public participation involves progressive degrees of engagement starting with providing information to instigate consultation that leads to involvement of the public representatives in the decision making which will eventually develops to active participation ${ }^{[10]}$.

\subsection{Challenges of Participation}

Experience of various countries especially those with long history of elected local councils presents a common challenge that relates to the notable decline in voter turnout at elections, which have serious implications for the legitimacy of local councils and the priorities they set for local issues ${ }^{[6]}$. This has led to important attention in part of governments to tackle this rising phenomena. Countries like Newzeland show a high appreciation of public participation with evidence that planners are increasingly, recognizing children and young people as legitimate participants in planning and local government as noted in the growth of participation initiatives undertaken by local councils ${ }^{[11]}$. It follows that most local authorities within democratic systems face two significant defiances; securing sustainable improvement to public services, and re-engaging local citizens with the institution of government $^{[6]}$. The interrelationship between the two challenges is vital. 
The more effectively citizens are engaged in shaping services and local planning the more likely that quality will improve.

Developing countries present a different concern which relates to the growth of urban communities and the choice of institutionalization of mechanisms for the selection, periodic evaluation, and replacement of representative elected councils ${ }^{[12]}$. The electoral system has an important function on the effectiveness of participation. Not withstanding, the importance of this issue, it is not the focus of the paper to examine electoral system but to emphasise on local councils' roles and improvements. More understanding of the challenges to public participation can be grasped from the following section.

\subsection{Methods}

Public participation in local decision - making can take a variety of forms depending on the type of decision being made, the time and budget available to encourage public input and the political and cultural circumstances of the decision $^{[9]}$. Methods of public participation may range from passive - one way information to interactive two way participation. However, four broad types of public participation can be found as shown in Table 1. It is worth mentioning that these methods are complementary to local elected councils within which participation is institutionalized by a defined legislative framework, therefore, the remaining of this review will focus on local councils as they may be closer to Municipal Councils in Saudi Arabia.

Table 1. Types of Public Participation.

\begin{tabular}{|l|l|}
\hline \multicolumn{1}{|c|}{ Method } & \multicolumn{1}{|c|}{ Activity } \\
\hline Traditional & $\begin{array}{l}\text { Public meetings, question and answer sessions, issuing of } \\
\text { consultation documents. }\end{array}$ \\
\hline Customer Oriented & Customer satisfaction surveys and opinion polls. \\
\hline $\begin{array}{l}\text { Innovative methods to } \\
\text { consult citizens }\end{array}$ & $\begin{array}{l}\text { Complaint procedures, suggestion schemes interactive Web-sites, } \\
\text { citizen's panels, lowers groups and referendums. }\end{array}$ \\
\hline $\begin{array}{l}\text { Innovative method to } \\
\text { encourage citizens } \\
\text { deliberation }\end{array}$ & $\begin{array}{l}\text { Environmental forums, visioning exercises, planning cells, citizens } \\
\text { juries. }\end{array}$ \\
\hline
\end{tabular}

Source: Adapted from Callanan, $2003^{[2]}$.

Local councils are set up through legislative constitution. They usually form the first tier of government that deals with local issues and they pose the first point of contact for those concerned with local issues. However, their composition depends on the electoral system adopted by 
each country, which varies among countries, but they are usually made up of locally elected councilors.

Duties and responsibilities of local councils vary between countries, United Kingdom presents a rich and long experience in setting and operating local councils, currently local councils in Britain have a defined number of duties but they all affect directly on the community.

\subsection{Factors Affecting the Operation of Local Councils}

This section presents a review of elements of particular relevance for preparing local councils for better practice to help learning from other experiences in functioning municipal councils in Saudi Arabia. Reviewing literature on Local Councils of selected countries shows a number of factors that impact the performance and achievements of local councils, the study includes experience of the United Kingdom which manifest a number of variables derived from government intension to improve the performance of local councils ${ }^{[13]}$, other variables were collected from other experience, such as Venezuela (www.vinisuelanalysis.com, 17.9.2005), and France ${ }^{[14]}$, see Table 2. The elements include different variables that can be categorized to two sets of variables.

Table 2. Factors affecting Local Councils' operation and performance.

\begin{tabular}{|l|c|}
\hline \multicolumn{1}{|c|}{ Factors from selected Countries } & Consolidated Factors \\
\hline - Information & Contextual Factors \\
- Innovation & - Legislation \\
- Funding & - Responsibilities \\
- Knowledge Management & - Councilors \\
- Efficiency / Effectiveness & - Public Policy \\
- Partnership with Community & - Relation with Central Government \\
- Organization and People Development & - Funding \\
- E-government & - Performance Assessment \\
- Procurement & - Vision \\
- Legislation & - Community Needs and Expectations \\
- Government Vision & Local Factors \\
- Leadership & - Organization: \\
& Structure Leadership capacity \\
& building \\
& - Information \\
\hline
\end{tabular}

Note: Factors from selected countries are depicted from a few references as shown above.

First, contextual factors are those which represent external factors within which local councils work, councils have very little to do to change them, they include legislation, National Policy and community 
needs. Second are local factors that constitute the internal environment within which the councils work including council organization, and information. It is hoped that the following review will pave the way to establish an analytical framework to examine the readiness of municipal councils in Saudi Arabia.

\section{Framework for Analysis}

The above section defined two sects of factors that interact together to determine the performance and achievements of the local councils. Figure 1 presents a conceptual view of how both sets of factor inter-relate and affect the operation and accomplishment of local councils. The framework follows an input-output model in which contextual factors define the inputs to the council determining the framework within which it works. Once the contextual factors are input to the system of the local council they interact with the local factors to process all relations and functions before producing outputs or achievements. This framework demonstrate abstract conception upon which Municipals Councils in Saudi Arabia can be studied. Although, it is early to examine municipal councils in Saudi as they just started to function, the proposed framework can help in examining the context within which they work and evaluating their readiness to function.

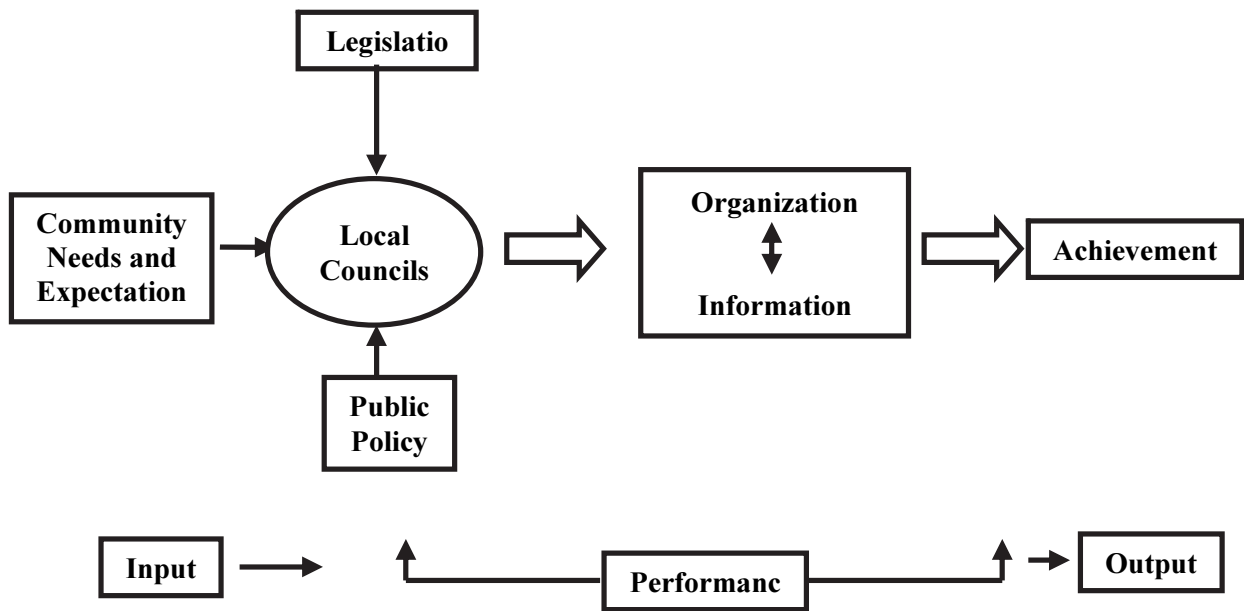

Fig. 1. Analytical Framework for Local Councils (Source: Author). 


\section{Development of Municipal Councils in Saudi Arabia}

Establishment and development of municipalities has long history in Arabia especially in Hejaz as it houses the two Holy Mosques of Makkah and Madina. Recent history started with the unification of the Kingdom of Saudi Arabia by Late King Abdulaziz. When he entered Makkah in $1343 \mathrm{H}(1923 \mathrm{G})$, King Abdulaziz ordered the formation of a local council from 12 elected members to help in managing city affairs. This council was developed to include all towns in Hejaz. Later in 1954 the Law of Municipality of Makkah and other Municipalities was enacted calling for the set up of Municipal Councils and defined councils' responsibilities and the relationship between municipalities and Municipal Councils. In 1977 the Law of Municipalities and Villages was issued to supercede the old Law of 1954 and reiterated the request to establish Municipal Councils and defined their composition, responsibilities and association with Municipalities. Councils were given the power to decide and monitor, while municipalities were empowered to implement. However, municipal councils were not instituted as requested and existing ones were unfit to function. It was until 2004 when the Council of Ministers announced that the Kingdom will hold elections for half the seats in 178 Municipal Councils spread throughout the Kingdom's 13 regions. The semi-selected Municipal Councils have varying numbers of members as shown in Table 3.

The election process for all councils finished in mid 2005 and names of elected members were announced. The remaining half of the council members were appointed in late 2005 marking the go ahead for councils.

Table 3. Composition of Municipal Councils.

\begin{tabular}{|l|c|}
\hline \multicolumn{1}{|c|}{ Cities } & No of Members \\
\hline Makkah, Madinah, Riyadh, Jeddah, Dammam. & 14 \\
Taif, Al-Ahsa, Abha, Hail, Buraidah, Tabuk, Jazan, Baha, Najran, Aljouf, & 12 \\
and North Boundaries. & 10 \\
Khamis Mushait, Unaizah, Alkharj, Hafr Al-Baten, and Yanbu. & 6 \\
Districts "Mohafadha" & 4 \\
Centres "Marakez" & \\
\hline
\end{tabular}




\section{Contextual Factors}

Contextual factors as discussed in section 2.4 include legislation, public policy, and community needs and expectations. These inter-related factors are examined below.

\subsection{Legislation}

The main legislation that governs Municipal Councils is the Law of Municipalities and Villages (1977) which specifies duties, formation and power bestowed upon municipal councils. Though the Law was passed for more than a quarter of a century, sections related to Municipal Councils were only activated in 2004 by the Council of Ministers, endorsing the beginning of the election of half members of Municipal Councils. The election process was regulated by a Ministerial Order ${ }^{[15]}$.

\subsubsection{Establishment of Municipal Councils}

A Municipal Council is defined in the Law of Villages and Municipalities (1977) as a semi-elected council that has the authority to decide and monitor municipal activities. Accordingly, Municipal Councils are confined to municipal functions which does not include major services such as schools, health facilities, water supply and sewage network. Municipal Councils are made up of equal number of elected and appointed members. Appointed members include the mayor and they are named by the Minister of Municipal and Rural Affairs (MOMRA). A chairman and his deputy are then chosen for two years by majority of the council members. Councils are legally obliged to hold up at least one meeting a month, to discuss council business. The council can appoint committees from its members to deal with specific subjects. Council meetings are closed and the council may invite any person that can be useful. Decisions of the council are passed by majority of votes and it is for the Minister of MOMRA to determine what decisions need endorsement, which is not defined yet.

The Law of Villages and Municipalities (1977) confers to the Minister of MOMRA to create Municipal Councils for a term of Four Years. Now as the election process is completed in accordance with regulations governing the election of half the members of Municipal Councils. In addition, Municipal Councils are formally formed by naming the other half of the members by the Minister of MOMRA in late 2005. Thus, councils already able to function and carry out their duties. 
Accordingly, a total of 178 councils of various municipal grades have been formed. However, a municipal council can be dissolved by the Minister of MOMRA if it proves to be incapable to fulfill its duties, and the council can be re-constituted with new members in accordance with governing regulations.

\subsubsection{Responsibilities of Municipal Councils}

Responsibilities of the Municipal Council are limited to decide upon municipal issues as stipulated in the Law of Municipalities and Village (1977) which are detailed in Table 4.

Duties of Municipal Councils are enclosed to municipal engagements and do not include all urban or city issues. By contrast municipal duties are varied, diversified and call upon municipalities to coordinate with concerned agencies in particular instances. Practically speaking, powers at the local level are cut up among three authorities (Fig. 2). First is the Amara and Mohafadhah Regional and District governates, which are concerned with keeping peace and order and supervise administrative issues. Second is the Municipality and third are local branches of central ministries. Each agency from the three divisions is answerable to its Central Ministry with some coordination at the local level.

Table 4. Municipal Council Responsibilities.

\begin{tabular}{|l|l|}
\hline \multicolumn{1}{|c|}{ Municipal Council } & \multicolumn{1}{c|}{ Municipality } \\
\hline - Decides on all Municipal issues in & - Organizes its area according to an endorsed \\
accordance with the Law of Municipalities & plan. \\
and Villages and other regulations, and in & - Issuing Permits for construction of \\
particular the following: & buildings and infrastructure. \\
- Review of Budget of Municipality. & - Preserving cleanness and city appearance, \\
- Endorses Final Accounts to be diverted to & arranges parks and open spaces, tourist \\
concerned agencies. & places, organizes and monitor them directly \\
- Putting zoning regulations and planning by & or indirectly. \\
e-Laws. & - Protects public health and clear all swamps, \\
- Proposing urban Projects. & avoid flood hazards and establish green \\
- Putting regulations needed for Municipality & belts around cities. \\
to implement its duties with regard to & - Monitors and inspects foods and consumer \\
environmental health, buildings and & goods including supply and prices, scaling, \\
municipal services and others ..... & and standards with participation with \\
- Determining on charges and penalties not & concerned agencies. \\
exceeding SR. 100. & - Builds and organizes slaughter houses. \\
- Proposing charges and penalties exceeding & - Builds markets and determines shopping \\
SR. 100. & areas. \\
- Monitoring income and expenditure of & - Permitting crafts and premises. \\
municipalities and manage its financial & - Preserves safety and comfort. \\
\hline
\end{tabular}


resources in accordance with rules and regulations.

- Monitors performance of the municipality and improve its efficiency.

- Proposes compulsory Acquisition Projects.

- Determine municipal service charges

- Provides opinion on matters put before the council.
- Determines locations of roaming sellers.

- Organizes transportation in coordination with concerned agencies.

- Public Acquisition.

- Determines and collects penalty charges.

- Supervises election of crafts' leaders.

- Promotes cultural, sport and social activities.

- Cooperates with other agencies to stop begging, and builds special houses for the disabled.

- Builds and operates cemeteries.

- Protects citizens from wild animals.

- Stops and eradicates any encroachment.

- Any other responsibilities defined by Council of Ministers.

Source: Gathered from Law of Municipalities and Villages (1977).

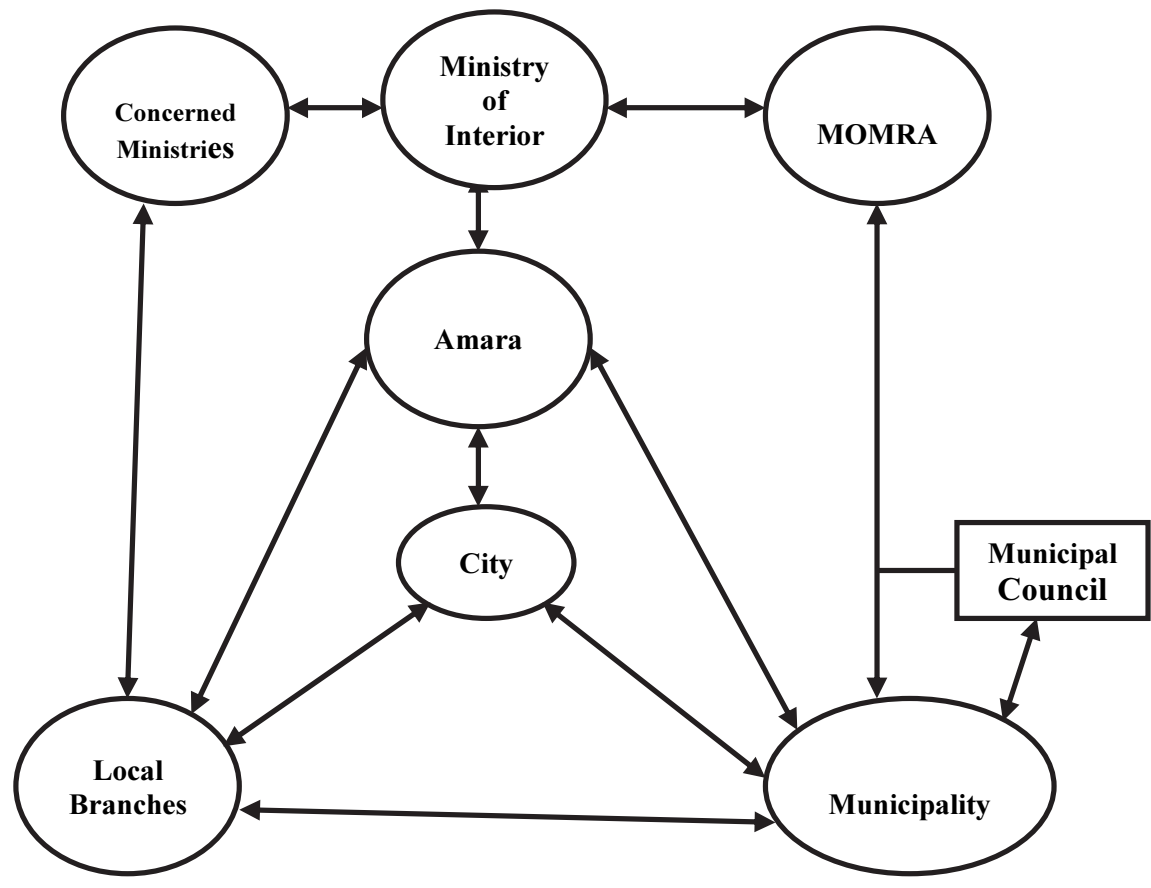

Fig. 2. Abstraction of Local Structure and City Development (Source: Author).

A Municipal Council will have to deal directly with its municipality which is somewhat engaged with harmonizing other agencies. However, municipalities have to deal with the introduction of Municipal Councils which will have the authority to decree and invigilate 
municipal activities. Municipal Councils are requested to put in place proper arrangements to ensure appropriate conduct of financial affairs of the municipalities, together with other activities, which will definitely require skills and preparation to handle all interrelated and diverse responsibilities. Though municipal councils are requested to fulfill all responsibilities outlined in Table 4, it is not yet clear from existing legislation what tools will be available to them to fulfill all these responsibilities. Municipal Councils will find themselves working in an interacting environment which include MOMRA, Local Municipality and the community as elaborated in section 5.2.2.

\subsubsection{Councilors}

The Law of Municipalities and Villages 1977 determined the criteria to qualify to be a member of the Municipal Council. Accordingly, a municipal council member shall be:

- $\quad$ Saudi citizen by blood or birth, or given Saudi Nationality for not less than 10 years.

- $\quad 25$ years of age or more.

- $\quad$ Resident at the city where council is located.

- $\quad$ Not convicted or prosecuted for any crime.

- $\quad$ Not expelled from public services for behavioral misconduct.

- $\quad$ Literate.

- $\quad$ Not convicted for illegal bankruptcy.

The recent election for membership in municipal councils was restricted to male citizens only, while inviting female participation was not arranged for and may be recognized in future. Further, the Law of 1977 outlined conditions upon which a person is disqualified from holding office as a municipal councilor. A member of the municipal council is elected or appointed for a term of four years. Saudi men fulfilling the above conditions are eligible to become members of the local councils. Elected and appointed members are supposed to reflect interests of local communities and promote a good local environment. Members of the council are required to attend meetings of the full municipal council and engage in committees that deal with specific subjects of the council business. Becoming a member of a municipal council is a challenge that put members in a position to where they work to make a difference to the quality of life at their locality. Elected and appointed members have to balance the needs and concerns of their 
residents and the municipal council. Although, members of the municipal council are not full time job-holders in their councils, they have to spare time on top of their personal duties to deal with legitimate claims of their city and people. It is, therefore, important that council members comprehend their tasks and capacities to act in subjective and accountable way. Responsibilities bestowed on municipal councils entitle council members to be acquainted with skills to deal with district representation, budget reviews, decision making, policy review and development, follow up and overview, regulations and community leadership. Given all these duties accorded on councilors, the public expect them to act in an honest way and to maintain upright behavior. Confidence on municipal council's members means that they are accountable for the expected performance standards from the public. So far, no code of conduct has been announced to specify provisions that direct members of municipal councils to the standard of behaviour assumed on them. Therefore, members will need orientation on conduct as well as training in skills needed before engaging in council business.

\subsection{Public Policy}

\subsubsection{Relationship of Municipal Councils with MOMRA}

Section 5.1.2 above elaborated on the position of Municipal Councils with the existing local structure of government. It is very obvious that MOMRA controls the organizational process within which Municipal Councils act, and also endorses certain decisions taken by municipal councils. The relatively high number of Municipal Councils (178) of various grades of municipalities makes the involvement of MOMRA to be fraught with difficulties. Existing practice shows that municipalities depend on MOMRA on many aspects, and therefore, MOMRA exercises extended controls upon them. It is indefinite whether the activation of Municipal Councils will ease the existing relationship between MOMRA and Local Municipalities or will add to its complexity. Municipal Councils will play a role that impact local citizens' life, which range from planning residential and employment places to caring for environmental health, therefore, municipal councils will affect the type of environment in the future. Such role will definitely need support in taking initiatives and establish proper partnerships at the local level. To accomplish their tasks, municipal councils will find it necessary to compromise between national and local priorities and to support 
municipalities in their effort to secure necessary funds for their programmes and give guidance to meet community needs (Fig. 3). Municipal Councils will have to put up a strategy and policy to deal with these issues, so that they acquire means to deliver what they want to achieve. Members of the municipal councils need to understand how community needs and expectations are interpreted in the strategy, how strategies are put for action and how they are monitored. Therefore, MOMRA is expected to have more to do in order to facilitate Municipal Councils' performance with increasing orientation towards realizing their local needs and expectations. This means finding new ways to work together so that citizens can feel a better delivery of services with rising quality. A new perspective for the relationship between MOMRA and Municipal Councils becomes important, to build more flexible and responsive interaction focusing on priority outcomes that need to be accomplished locally.

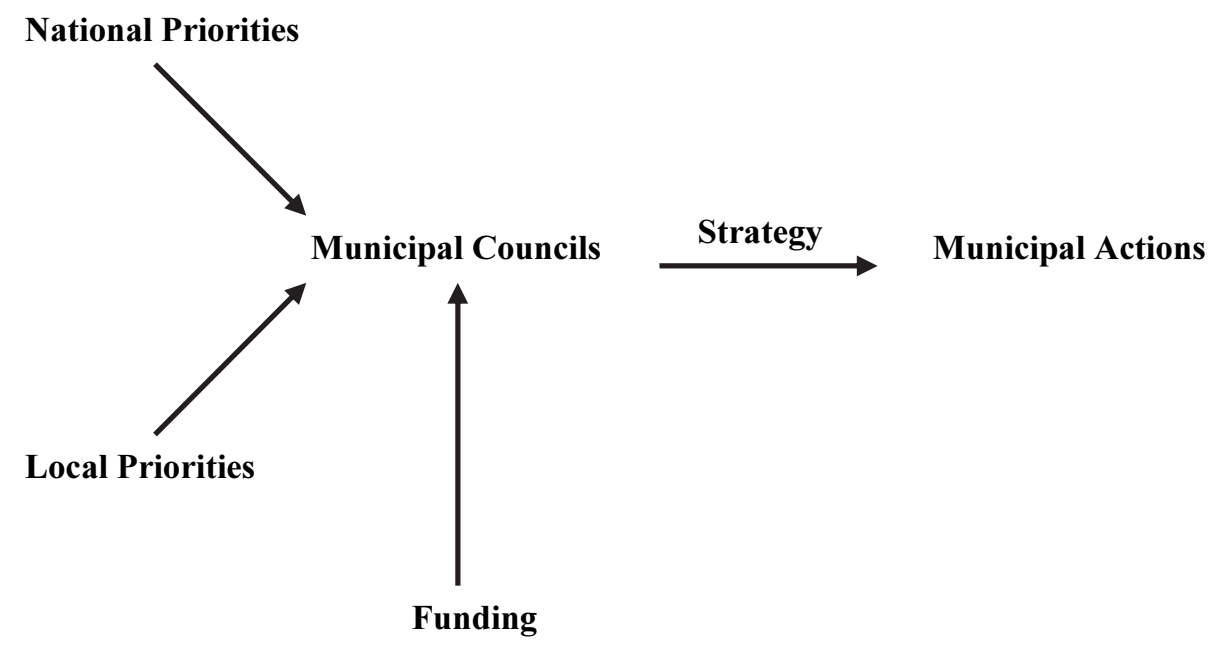

Fig. 3. Inputs to Municipal Councils.

\subsubsection{Funding}

Financial resources play a significant role in the function of any organization. Currently municipalities rely enormously on government fund. Few municipalities show positive results in increasing their local revenues, but cannot go without central support. For example revenues of the Municipality of Jeddah constitutes less than $25 \%$ of its expenditure ${ }^{[16]}$. Most municipal services are provided with no charge to citizens or those who benefit from them. In addition, Municipalities do 
not levy tax and their revenue mainly comes from letting public properties, charges on advert sings and posts, and collection of penalty charges. Municipal Councils will have to deal with a sensitive issue to increase municipal fund to spend on better services. In fact, revenue, budget, and expenditure of the municipality represent central challenges that call municipal councils to strike a balance to make their policies and strategies come alive. Revenue, budget and expenditures are expressed in monetary terms but cover wide issues.

Therefore, members of municipal councils are required to apprehend all the resources available to municipalities and how can they best used. In particular, municipal council members need to be aware of:

- Linking policies to budget,

- setting priorities for expenditure,

- sources of fund,

- fund raising,

- dealing with expected expenditure, and

- solve current issues in municipal finance

\subsubsection{Performance Assessment}

Municipal Councils work in an environment which includes MOMRA, the Local Municipality, and the community. (Fig. 4) Such context will definitely require accountability that needs transparent working environment and strong performance measurement. Municipal Councils are entrusted by the community (though semi-elected) to follow-up municipal activities, and their performance shall be available for the public. Therefore, on one hand, there is a need for performance evaluation to be applied on municipalities by the Municipal Councils, and on the other hand, there is a need for assessment of Municipal Councils by MOMRA, and both assessments shall be available for the community. One of the duties given to Municipal Councils is to monitor and evaluate performance of municipalities. Before the initiation of municipal councils in late 2005, municipalities enjoyed a single selfauthority with varying degree of autonomy from MOMRA according to their grade or rank. Given the wide range of functions done by municipalities, municipal councils need to establish a systematic approach for their monitoring mission. A solid performance valuation is needed to facilitate this task which will require assessment of financial expenditure and conduct on other aspects. Urban indicators might be 
necessary to rationalize the follow up process. The fresh experience associated with the launch of municipal councils needs to be supported by practical tools to assist the councils to carry out their duties. MOMRA is in a position to provide central guidance to the newly created councils to pave the way for a steady start for these councils and also to reduce confusions on their way.

The very nature of performance valuation comes from the value for money which become one of the factors that have promoted the spread of performance measurement systems at the local level ${ }^{[17]}$.

Equally important is the accountability of municipal councils to the community which entails the institution of a performance valuation on their conduct which will (a) give them guidance on what they need to achieve and (b) to make the community aware of their performance because half of their members are elected. In addition, an orderly organized performance management method is essential to be deployed to systematically evaluate and improve the conduct of municipal councils throughout the Kingdom. An effective performance valuation system have to emphasise on (a) meeting community needs in an effective way (b) providing greater accountability to local community (c) incorporating national priorities (d) continuous modernization of working methods geared towards e-government.

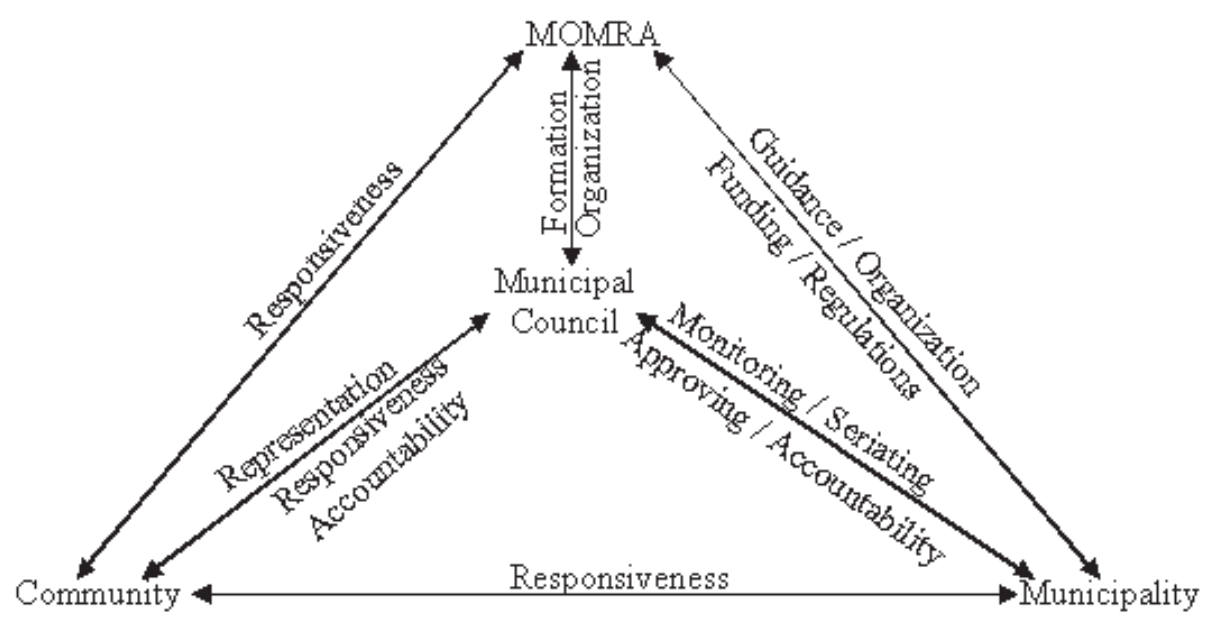

Fig. 4. The Working Context of Municipal Councils.

The performance framework should focus on outcomes which require municipalities to adopt robust performance system. In fact 
municipalities must face challenges to introduce effective ways to improve the obdurate underperformance. The performance management aims at presenting timely and useful performance information to sustain its credibility.

Moreover, performance measurement is central to directions for a more efficient, effective and accountable public sector ${ }^{[18]}$. There are different methods of performance management, such as, first, traditional methods focusing on economic indicators and efficiency due to limitations to calculate effectiveness or outcomes ${ }^{[19]}$. Second are methods which add the non financial measures ${ }^{[20]}$. MOMRA may need to outline the path for introducing Performance Measures and Programme Evaluation that suits municipal councils' responsibilities and accounts for municipalities' conduct and achievements. Municipal Councils should also be helped to find the right tools and methods to monitor and continually evaluate programs and issues within their responsibilities.

\subsubsection{Vision for Future}

Currently there is a clear division of obligations and duties at the local structure in cities and towns as outlined in section 5.1.2. Given the vital role played by each government body and the need in running city's business and development which demands a more unified administration, management and operation to support the development of sustainable communities. Municipal Councils need to be supported to work in a context that makes them more effective and accountable to local communities to meet their demands and expectations. There is a need to establish a vision and to develop a perspective of what local administration and municipal councils in Saudi Arabia would look like in a specific time of the future. This vision requires a great deal of thinking and discussions for providing a better life within our cities and towns in a rapidly changing world. A new vision shall deal with improving and developing a more consolidated local administrative structure in relation to more effective regional authorities. It is necessary to develop a long term approach to amalgamate local administration that is capable at performing stronger leadership, allowing effective citizen engagement, responding to community needs and delivering services in a satisfactory way. Finally, the awaited vision needs to capitalize on the call of the council of Ministers for electing half members of the municipal councils to put people at the centre of urban and rural development. Once the 
vision for local administration is set, a framework for implementation must be prepared to assure outcomes.

\subsection{Community Needs and Expectations}

The inauguration of Municipal Councils in late 2005 instigated a transition in community engagement from ad hoc consultation to a recognized part of government. The introduction of elected members to the semi-elected councils represents a steep learning curve to all engaged in the running out and controlling of municipal decisions. The transition process shall satisfy the four concepts of public participation defined in section 2.1 which include (a) delegation of the public to the municipal council to take decisions, (b) accountability, (c) responsiveness and (d) representativeness. Figure 5 presents a perspective on how these elements integrate with municipal council's functions, its operation with MOMRA, Municipalities and the community. The semi-elected councils are authorized through a representative process to take decisions on behalf of their community, most important are those related to needs and priorities which are then, passed to municipalities for implementation, thus working with MOMRA and other government units. A key objective to the municipal council is to develop ways for citizens to contribute to the decisions taken on their behalf. In the mean time, the council and municipality have to learn to operate within the specific structures of government (local, central), to do budgeting, fund raising, planning and service delivery. This emphasizes the importance of making an effective transition for the municipality's work environment. Further more, municipal councils' credibility depends on the way they respond to public needs and accountability involved. Therefore, councils are requested to maintain good levels of contact and exchange of information with the community.

There is a wide diversity in the approaches available to ease citizens' engagement in the decision making process at the local level as exhibited in Table 1. There is no single right way, and municipal councils form only one option that can be complemented by other methods to keep up with rising needs and expectations of the community. Therefore, municipal councils shall try to increase ways for people to get involved in local issues, and how best to build the capacity of the society to engage more effectively in issues of concerns to them. 


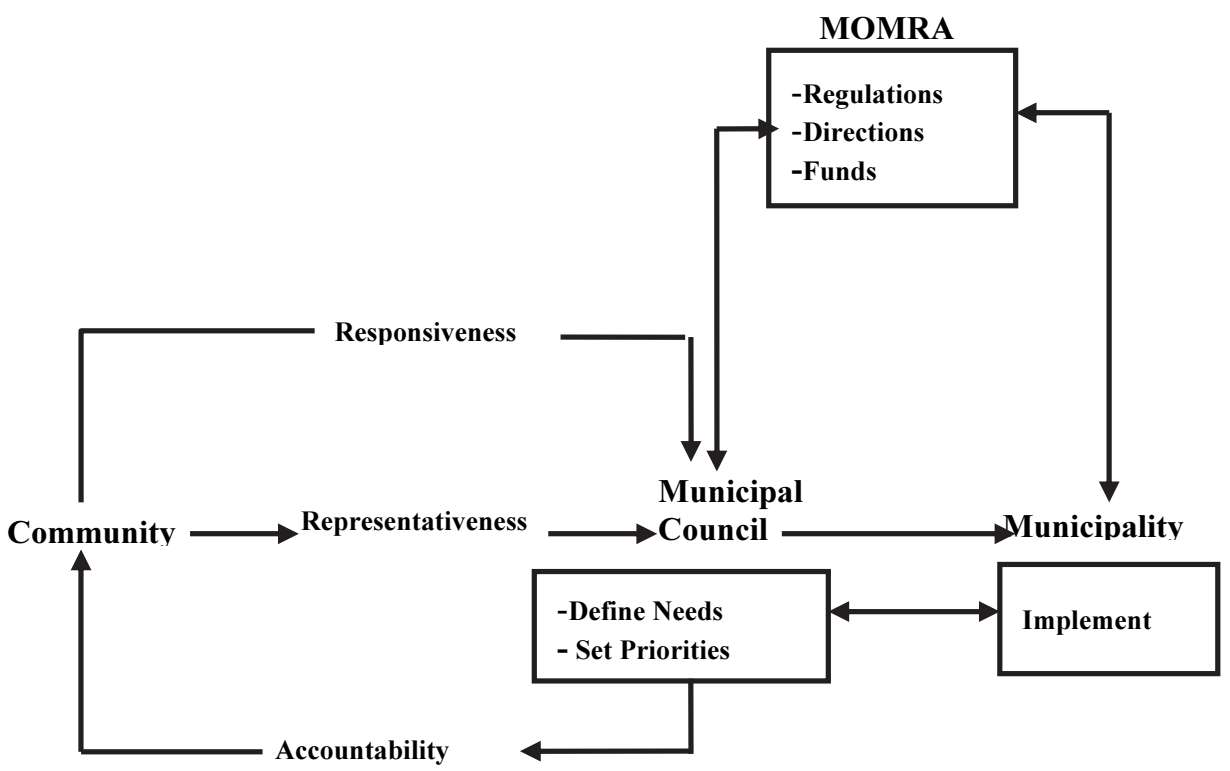

Fig. 5. Communication between Community and Municipal Councils.

\section{Local Factors}

\subsection{Municipal Councils' Organization}

Organization of municipal councils' involves three inter-related elements including: council structure, leadership and capacity building. In fact a successful organization contributes to the creation of an environment that is challenging and promotional for its members. Municipal councils form an authority of the municipality, and therefore, they are part of a large organization. So far, the structure of councils and their internal organization is not yet disclosed. For municipal councils to function well, councils have to develop a suitable organization and to set out rules and procedures to adhere to. This will help municipal councils to have an internal framework to reinforce the council in carrying out its business and making decisions. The legal framework set forth by the Law of 1977 and subsequent regulations from MOMRA have to be detailed by technical documents that describe the organization of municipal councils and how they work. In addition, new members of municipal councils need to be familiarized with legal and organizational issues related to council set up, business and conduct. The Law of Municipalities and Villages (1977) requested that each newly established municipal council 
shall have a chairman and a deputy selected by its members. Most important is that municipal councils shall be run by vibrant leaders who lead and advocate local areas, strive for better outcomes for their people, able to decide on priorities for their areas and being accountable for the choices made. Accordingly, they become respected by the community they work for. The perception of municipal councils may need to be developed to make councils as community leaders. The existing responsibilities accorded upon municipal councils give them leading roles which have to be managed by comparable high caliber members to lead councils with the ability to shape and communicate the purpose of their councils. MOMRA needs to continue emphasizing the (i) importance of municipal councils as strong and effective community leaders, and (ii) the semi-elected councils are accountable with a mandate to apply the contributions to tackle rising problems.

In fact there are three main challenges for the leadership issue that face municipal councils ${ }^{[6]}$ which includes:

(i) Producing effective local leadership.

(ii) Stimulating the supply and remove barriers.

(iii) Equip leaders with the skills and qualifications needed.

These challenges do not seem to have been properly addressed by existing legislation and context prepared for municipal councils. Figure 6 exhibits a view of what is expected to be attempted by MOMRA and municipal councils. MOMRA being a central authority is in a position to set the legal framework and to help in prorating the capacity building of municipal councils and municipalities to facilitate the setting of institutional arrangements that can achieve community's needs. People drive organizations, and their leadership will make a difference, therefore, there is a continuing demand to invite, enroll, retain and develop larger group of diverse and talented individuals to represent and lead local communities ${ }^{[21]}$. Capacity building for both municipal councils and municipalities becomes equally important to cope with changing circumstances.

Leadership and capacity building shall aim at (i) removing barriers between municipal councils and municipalities, (ii) promoting skills and experiences of members of the council and municipality staff and (iii) producing leaders at different levels of decision making structure to sustain supply. 


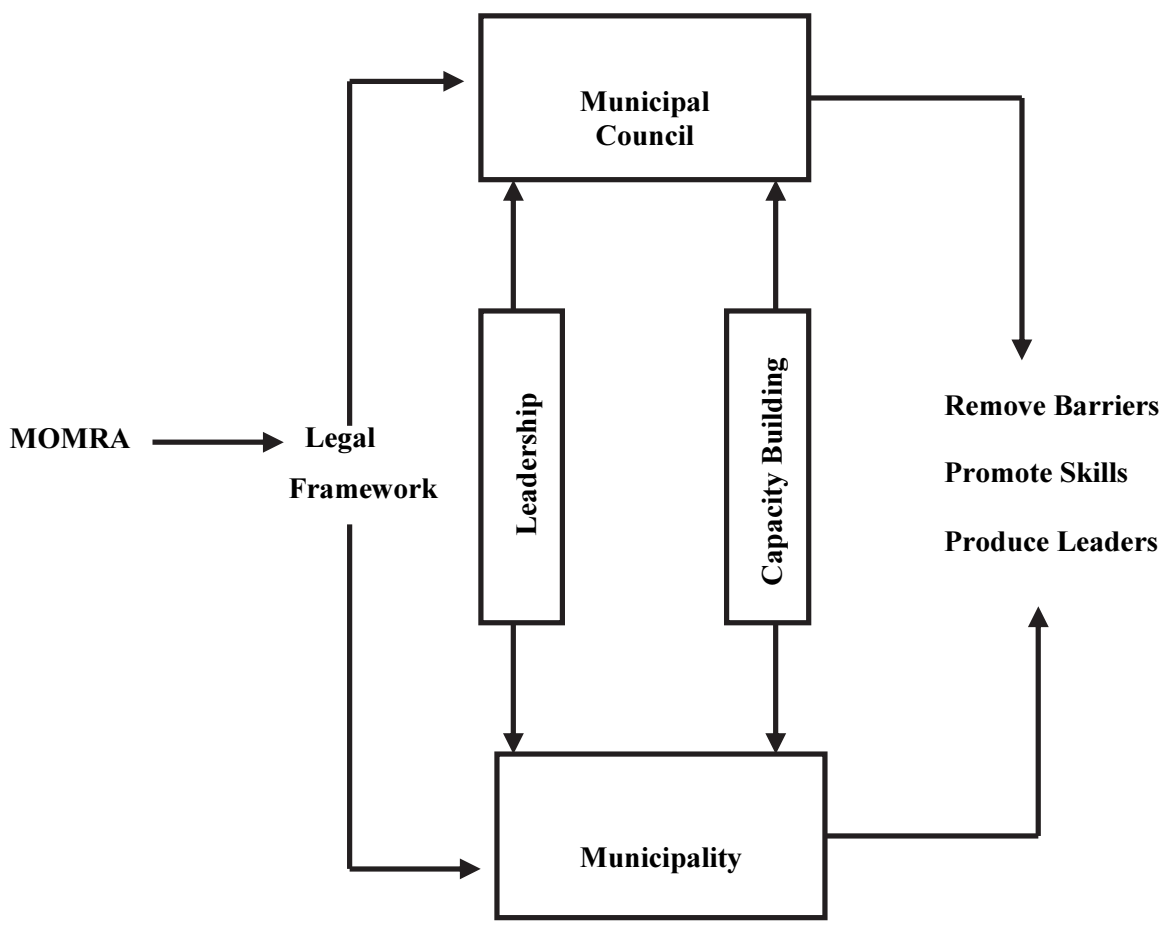

Fig. 6. Addressing the Issue of Leadership for Municipal Councils (Source: Author after British experience ${ }^{[6]}$ ).

\subsection{Information and Communication}

Information and communication are integral parts for the success of any organization as both of them establish and facilitate other parts of the framework within which municipal councils work. Municipalities possess huge data about their localities; data is usually stored at different individual departments undermining their capacity to be used as an integral data base for the city. The new municipal councils will need information in timely, regular and robust way to enable them to function and to take decisions. However, the current information environment at most municipalities need to be improved to present high quality and accessible information that accommodates needs of the different levels within the framework that municipal councils work. Information needs include providing information to the requests of the public, MOMRA, local administrators, sectoral departments, the Amarah, etc. Not withstanding the varying needs for information, it is possible to 
categorize information for the sake of an effective information system as follows:

- Performance indicators: the wide variety of responsibilities of municipal councils entails the existence of a sound follow up system based on predefined indicators to systematize and facilitate council's mission.

- Internal information system: Municipal Councils require that information is circulated internally including reporting to members of the councils and other parts within the structure of councils.

- Community information: Municipal Councils are working for their communities and therefore, they have an obligation to let the community be informed about their performance.

Credibility of any information systems depends on the quality and timeliness of data they provide. Municipal councils will depend heavily on municipal data which require a lot of improvement on the way they are collected, stored retrieved and up dated. The criteria used by the British government for the future of the Information System for their local councils manifest a good reference that are based on ${ }^{[22]}$ :

- Robust definitions of data and indicators.

- Comparability of information.

- Stability in the definitions of measures and indicators to minimize the burden of collection and enable comparison overtime.

- Transparent systems for gathering and accessing information to minimize bureaucracy and duplication.

- High quality and timely data.

- Right spatial level: to allow service providers to understand different patterns of need across their areas.

- Better aggregation of information to enable clearer overall patterns of performance to be established at various levels.

- Accessibility of information to all those who need it. 
- An appropriate balance between subject performance information, such as feed back from surveys and focus groups and quantitative data.

The key issue in Saudi Arabia is to find ways to start making enhancement more instantly, building on others experience to develop what municipal councils will need to support their work and facilitate their decision making.

\section{Preparing Municipal Councils}

The forgoing discussion highlighted the importance of municipal councils given the responsibilities bestowed on them. However, it is found that the context within which they will work and their internal organization can be prepared in a productive and effective way. This section aims at summarizing what can be done to furnish municipal councils to carryout their business. Table 5 outlines the possible preparation for municipal councils in relation to each of the contextual factors and internal factors along with the type of action needed by the concerned agency namely; central government, MOMRA, Municipal Council, Municipality and the Community. It is very obvious that the legislative factors form the driving force for the formation and operation of municipal councils. It is expected that beginning of will gradually allow the codification of the process of activating municipal councils new legislation to cope up with arising needs and changing circumstances. The actions pinpointed at Table 5 are proposed on light of what is requested to broaden the scope of municipal councils and to increase citizen engagement and representation.

Public policy stands behind legislation to achieve government objectives, consequently forming a vital role in shaping the progress of municipal councils. The most important process here is of devolution. The initiation of the election process means a call for public participation in decision making which can only be feasible by residing more power at the local level. The process of consultation and citizen engagement naturally develops to more empowerment to local authorities which will be more effective by a clear vision for the future of local structure and its relationship with central government. Performance assessment is a systematic process deemed necessary to guide municipal councils, 
rationalize their work and evaluate their achievements. The focus here is towards outcomes that can be measured against predefined indicators.

Finally local factors demonstrate equal importance as they are inherent to the internal functioning of municipal councils. The central issue here relates to the organization of the council and the information system followed. Municipal councils shall be organized in a way to meet community needs and expectations, and shall be equipped by effective leadership. Given the fresh start of municipal councils, capacity building is necessary to develop and promote skills and experiences deemed necessary for council members.

Information system becomes the backbone of any organization which shall be developed in accordance with the criteria proposed in the previous section.

Notwithstanding the importance of the suggestions presented in Table 5, municipal council can start with the available context; hence this is a continually learning process that requires ongoing changes that target a clear vision.

\section{Conclusions}

This paper focused on the potentials of municipal councils in Saudi Arabia, mainly the context within which they will work in and the local factors that are inherent to their set up and operation. Hence, municipal councils are semi-elected bodies, they contrive a serious call for public engagement in the decision making at the local level. Therefore, the paper started by reviewing literature on public participation in general to establish a framework to examine the fresh formation of municipal councils in Saudi Arabia. The analytical framework highlighted two sets of inter-related factors i.e. contextual and local factors. The examination of both sets of factors outlined the existing shortcomings and the actions needed for better preparation of municipal councils. It is concluded that nothing stops municipal councils from continuing their initiation process, and the proposed improvements can best be linked to a continuing learning process associated with the call for growing citizen participation in decision making at the local level. 
Table 5. Preparations for Contextual and Local Factors.

\begin{tabular}{|c|c|c|c|c|c|c|c|}
\hline & Factors & $\begin{array}{c}\text { Suggested } \\
\text { Action }\end{array}$ & $\begin{array}{c}\text { Central } \\
\text { Government }\end{array}$ & MOMRA & $\begin{array}{c}\text { Municipal } \\
\text { Council }\end{array}$ & Municipality & Community \\
\hline 卺 & $\begin{array}{l}\text { Legislation: } \\
\text { - Establishment } \\
\text { of municipal } \\
\text { Council } \\
\text { - Responsibilities } \\
\text { - Councilors } \\
\text { Public Policy } \\
\text { - Relationship } \\
\text { with } \\
\text { MOMRA } \\
\text { - Vision } \\
\text { - Funding } \\
\text { - Performance }\end{array}$ & $\begin{array}{l}\text { Broader scope } \\
\text { Increase } \\
\text { representation } \\
\text { Increase turnout } \\
\text { at } \\
\text { elections } \\
\text { More coverage } \\
\text { to } \\
\text { local issues } \\
\text { Capacity } \\
\text { building } \\
\text { Code of conduct } \\
\\
\text { Devolution } \\
\text { Mramework } \\
\text { Term vision for } \\
\text { local } \\
\text { Administration } \\
\text { Widen sources } \\
\text { of } \\
\text { Finance }\end{array}$ & $\begin{array}{l}\text { Reform Local } \\
\text { Administration } \\
\text { Progressive } \\
\text { inclusion of } \\
\text { local } \\
\text { issues } \\
\text { For local } \\
\text { government }\end{array}$ & $\begin{array}{l}\text { Gradual } \\
\text { increase of } \\
\text { Power to } \\
\text { Councils } \\
\\
\text { Promote } \\
\text { election } \\
\text { process, } \\
\text { Building } \\
\text { credibility of } \\
\text { councils } \\
\text { Call for more } \\
\text { involvement in } \\
\text { daily affairs } \\
\text { Develop } \\
\text { Training } \\
\text { Programs and } \\
\text { Skill Promotion } \\
\text { - Put ethics' } \\
\text { standards } \\
\text { More } \\
\text { empowerment } \\
\text { to councils } \\
\text { Relax } \\
\text { regulations } \\
\text { on fund raising } \\
\text { Propose } \\
\text { assessment } \\
\text { approach } \\
\text { Define } \\
\text { indicators } \\
\text { For Municipal } \\
\text { Councils and } \\
\text { Municipalities }\end{array}$ & $\begin{array}{l}\text { Apply and feed } \\
\text { Back } \\
\text { Monitor and } \\
\text { resort on results } \\
\text { Put up a } \\
\text { strategy to } \\
\text { balance } \\
\text { national } \\
\text { and local } \\
\text { priorities } \\
\text { Support } \\
\text { Municipality to } \\
\text { get enough } \\
\text { Funds } \\
\text { Apply } \\
\text { approach } \\
\text { Apply indicator } \\
\text { Feed back on } \\
\text { improvements }\end{array}$ & $\begin{array}{l}\text { Prepare logical } \\
\text { requirements } \\
\text { Find new ways } \\
\text { to partner with } \\
\text { others to meet } \\
\text { community } \\
\text { needs } \\
\text { Prepare } \\
\text { information } \\
\text { Develop sound } \\
\text { information } \\
\text { systems. } \\
\text { Spell out local } \\
\text { information } \\
\text { issues and } \\
\text { requirements }\end{array}$ & $\begin{array}{l}\text { For wider } \\
\text { community } \\
\text { engagement }\end{array}$ \\
\hline ]ृ & $\begin{array}{l}\text { Organization } \\
\text { - Council } \\
\text { Structure } \\
\text { - Leadership } \\
\text { - Capacity } \\
\text { building } \\
\text { - Information }\end{array}$ & $\begin{array}{l}\text { Continuous } \\
\text { improvement } \\
\text { - Produce } \\
\text { effective } \\
\text { leadership } \\
\text { - Stimulate } \\
\text { supply } \\
\text { of leaders } \\
\text { - Train leaders } \\
\text { - Develop } \\
\text { programmes } \\
\\
\text { Reform } \\
\text { Information } \\
\text { System at } \\
\text { municipalities }\end{array}$ & & $\begin{array}{l}\text { - Propose } \\
\text { Encouraging } \\
\text { - Environment } \\
\\
\text { - Develop } \\
\text { Program } \\
\text { - Set guidelines }\end{array}$ & $\begin{array}{l}\text { Take initiatives } \\
\text { to organize } \\
\text { Competitive } \\
\text { working } \\
\text { environment } \\
\\
\text { Apply and } \\
\text { Feedback / } \\
\text { Take initiatives } \\
\text { Apply and } \\
\text { Feedback }\end{array}$ & $\begin{array}{l}\text { Apply and } \\
\text { Feedback / } \\
\text { Take initiatives } \\
\text { Provide } \\
\text { enterprise } \\
\text { information } \\
\text { system: } \\
\text { - Demand } \\
\text { Information } \\
\text { - Collect data } \\
\text { - Synthesis } \\
\text { - Provide at } \\
\text { right time, } \\
\text { format, and } \\
\text { quality }\end{array}$ & $\begin{array}{l}\text { Accountability } \\
\\
\text { - Increase } \\
\text { public } \\
\text { involvement } \\
\end{array}$ \\
\hline
\end{tabular}




\section{References}

[1] Council of Ministers (2004) Resolution No. 24, dated 17/8/2004.

[2] Callanan, Mark (2003) Institutionalizing participation and governance? An analysis of new local government structure in the Republic of Ireland. A paper presented to the EUROLOC Network, Eighth European Summer School in Local Government at University College Cork.

[3] Beetnam, David (1996) "Theorizing democracy and local government," In: D. King and G. Stoker (eds.) Rethinking Local Democracy, London, Macmillan.

[4] Walsh, K. and Sarkissian, W. (2001) Effective community participation: Best value listening at the local level. Best Value Conference, Melbourne.

[5] Chanan, G. (1997) Active citizenship and community involvement: getting to the roots. Dublin: European Foundation for the Improvement of Living and Working Conditions.

[6] ODPM, Office of the Deputy Prime Minister (2005) Citizen Engagement and Public Services: Why Neighborhood Matters, Home Office Publications, London.

[7] Gauci Emmanuel (2001) Building community participation in local democracy - The Whitehose Experience, http://www.une.edu.au/clg/lgconf/papers/gauci.htm, 4/1/2006.

[8] Department for Environment, Food and Rural Affairs (2004), Partial regulatory impact assessment on proposed regulations to transpose in England and Wales, The European Council Directive 2003/35/EC.

[9] U.N. Development Programme (2003) World Resource 2002-2004: Decisions for the earth balance, Voice and Power. U.N. Environmental Programme.

[10] Kent County Council (2005) Enabling Choice-Making a Change, Public Publication, Kent.

[11] Freeman, Claire and Aitken-Rose, Elizabeth (2005) Future shapers: children, young people, and planning in New Zeeland local government, Environment and Planning C: Government and Policy, 23(2): 227-46.

[12] Ndioy Mumar (1998) The impact of electoral reform at the local level in Africa: The Case of Senegal's 1996 Local Elections, Electoral Studies, 17(4): 463-82.

[13] ODPM, Office of the Deputy Prime Minister (2004) The Future of Local Government, Eland House, London.

[14] Hubercht, Hubet and Capes, David (2004) "Councils for development": A major opportunity for participatory governance in France. IEP de Bordeaux, University Montesquieu, Bordeaux IV.

[15] Ministry of Municipal and Rural Affairs (2004) Ministerial Order No. 38396, 15/6/1425.

[16] Jeddah Municipality (2005) Budget report, Unpublished.

[17] Palmer, A. (1993) Managerialism and the Public Services, Oxford, Blackwell.

[18] Guturie, J. and English, L. (1997) Performance information and program evaluation in the Australian public sector, International Journal of Public Sector Management, 10(3).

[19] Kloot, Louise and Marlin, J. (2000) Management accounting research, doi: 10.1006/mare.

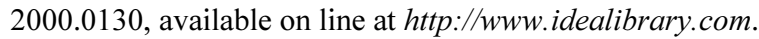

[20] Emmannel, C., Otley, D. and Merchant, K. (1990) Accounting for Management Control, London, Chapman and Hall.

[21] ODPM, Office of the Deputy Prime Minister (2005) Vibrant local Leadership, Eland House, London.

[22] ODPM, Office of the Deputy Prime Minister (2005) Securing Better Outcomes: Developing a New Performance Framework, Eland House, London. 


\section{المجالس البلدية بالمملكة العربية السعودية: الإطار والتنظيم}

\section{وليد عبدالله عبدالعال}

قسم التخطبط الحضري والإقلبيه، كلية تصاميم البيئة، جامعة الملك عبدالعزيز علئ

$$
\text { جدة - المدلكة العربية السعودية }
$$

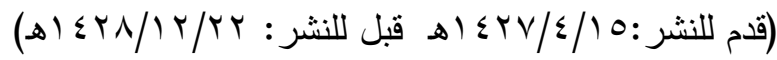

الدستخلص. أقر مجلس الوزراء السعودي في عام ع ـ. بام تشكيل

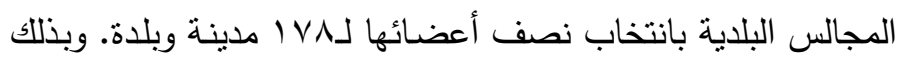

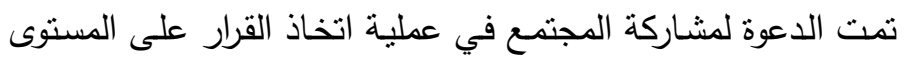

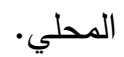

من المفهوم أن العملية الانتخابية قد أنجزت في أوائل عام البام

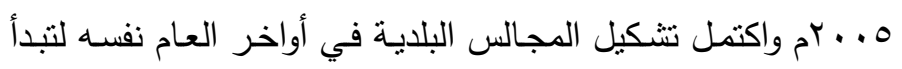

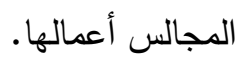

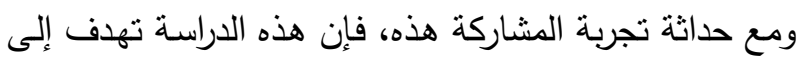

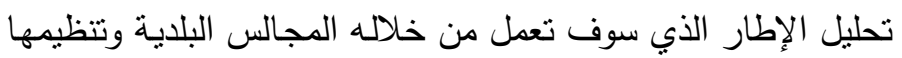

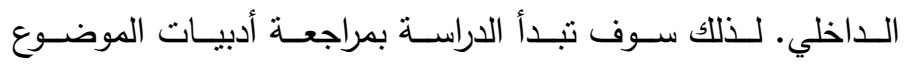

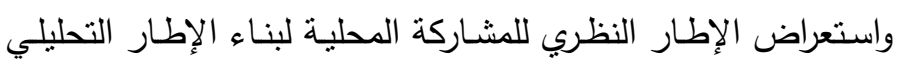

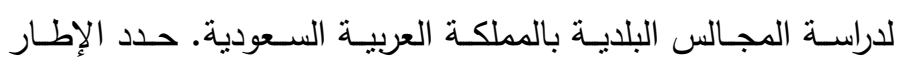

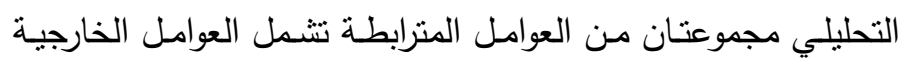

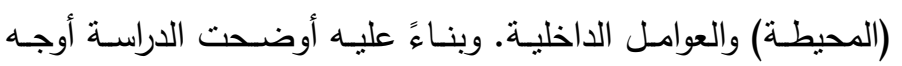

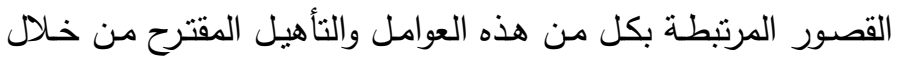

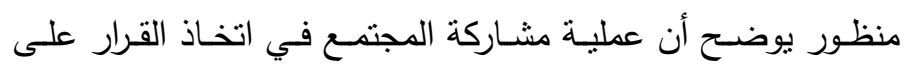

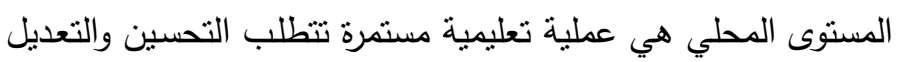

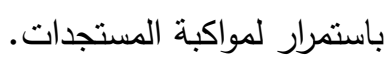

